\title{
Organizing Sumber Daya Panti Asuhan Muhammadiyah Lhokseumawe dalam Pembinaan Akhlak Anak Asuh
}

\author{
Almuhajir \\ IAIN Lhokseumawe \\ abujaadalhaq@yahoo.com
}

\begin{abstract}
This study aims to explain the organizing of Muhammadiyah Lhokseumawe orphanage resources in fostering the morals of foster children. This research is a qualitative research using a phenomenology approach. The results showed that organizing the resources of the Mubammadiyah Lhokseumawe orphanage in the moral formation of foster children globally had carried out their duties and mutual coordination. The Chair, coordinates and evaluates the management and cooperation with various stakeholders, both government and private. Secretary, takes care of internal and external administration of the institution. Finance, records, compiles and oversees the entry and exit of money from various parties for the needs of foster children. The field of Education, Supervision and Order is responsible for formal and nonformal education of foster children, supervises various activities, and cooperates with third parties in handling security. The field of Health and Hygiene, handles the bealth and bygiene of foster children both practically and in a mindset. Various job descriptors that are in the management structure of Mubammadiyah Orphanage in Lhokseumawe, handling the problem of the moral development of foster children are fully entrusted to the field of care.
\end{abstract}

Keywords : Organizing; Moral Development; Orphanage; Foster Children.

\begin{abstract}
Abstrak : Penelitian ini bertujuan untuk menjelaskan organizing sumber daya panti asuhan Muhammadiyah Lhokseumawe dalam pembinaan akhlak anak asuh. Penelitian ini merupakan penelitian kualitatif dengan menggunakan pendekatan fenomenologi. Hasil penelitian menunjukkan bahwa organizing sumber daya panti asuhan Muhammadiyah Lhokseumawe dalam pembinaan akhlak anak asuh secara global telah menjalankan tupoksinya dan saling koordinasi. Ketua, melakukan koordinasi dan mengevaluasi pengurus dan kerjasama dengan berbagai stakeholder, baik pemerintah maupun swasta. Sekretaris, mengurus administrasi internal dan eksternal lembaga. Bidang Keuangan, mencatat, menyusun dan mengawasi keluar masuknya uang dari berbagai pihak untuk kebutuhan anak asuh. Bidang Pendidikan, Pengawasan, dan Ketertiban, bertanggung jawab terhadap pendidikan formal dan non-formal anak asuh, melakukan pengawasan terhadap berbagai kegiatan, serta bekerjasama dengan pihak ke tiga dalam menangani keamanan. Bidang Kesehatan dan Kebersihan, menangani kesehatan dan kebersihan anak asuh baik secara praktis maupun pola pikir. Berbagai job deskription yang ada dalam struktur kepengurusan Panti Asuhan Muhammadiyah Lhokseumawe, penanganan masalah pembinaan akhlak anak asuh dipercayakan sepenuhnya pada bidang Pengasuhan.
\end{abstract}

Kata Kunci : Organizing; Pembinaan Akhlak; Panti Asuhan; Anak Asuh.

\section{Pendahuluan}

Pengorganisasian dalam sebuah organisasi memiliki peran yang sangat signifikan, sebab pengorganisasian merupakan penggabungan sumber daya manusia dan sumber daya lain dalam sebuah sistem organisasi. Dalam proses organizing dilakukan pembagian job description, wewenang, dan tanggung jawab secara detail berdasarkan bagian dan bidang masing-masing, sehingga terintegrasikan hubungan-hubungan kerja yang kondusif, sinergis, seirama, dan harmonis dalam mencapai tujuan yang telah disepakati dalam sebuah organisasi (Saefullah, 2012). 
Akhlak merupakan bagian penting dari sumber daya manusia yang harus diperhatikan dan dimanage. Pembinaan akhlak dewasa ini ramai dibicarakan untuk dikembalikan lagi pada substansi pendidikan, karena pendidikan tanpa akhlak hanya akan membuat individu manusianya tumbuh secara parsial, yakni menjadi individu yang pandai dan cerdas, tetapi minim pertumbuhan dari sisi moral secara lebih sempurna sebagai manusia. Pembinaan akhlak diharapkan mampu mengatasi berbagai problematika moral yang sedang terjadi di tengah bangsa ini.

Seiring dengan perkembangan zaman, teknologi dan gaya hidup masyarakat juga ikut berkembang. Teknologi semakin modern dan semakin efektif dalam penggunaan dan pemanfaatannya. Modernisasi ini selain membawa dampak positif yakni pengefisienan dan pengefektifan terhadap aktivitas yang dilakukan masyarakat, namun juga membawa pengaruh buruk atau dampak negatif terhadap masyarakat pula, terutama di kalangan remaja. Kenakalan remaja salah satu problematika yang sering memunculkan kegelisahan sosial karena jaringannya bisa menimbulkan kemungkinan "gap generation", sebab mereka yang diharapkan menjadi regenerasi serta calon-calon pemimpin bangsa yang akan datang banyak yang terjerumus ke dalam dunia kehinaan.

Untuk membendung fenomena tersebut di atas, Panti Asuhan mengambil peran untuk menangani problema masyarakat tersebut sebagai salah satu media untuk pembinaan akhlak pada anak-anak atau remaja muslim. Panti Asuhan merupakan lembaga sosial yang memiliki fungsi dan peran untuk mengelola anak yatim, yatim piatu, dan terlantar untuk mendapatkan penghidupan yang layak seperti anak normal lainnya, baik secara lahir maupun batin.

Suratman (2015) sebagai Child Protection Specialist Save The Children Indonesia menjelaskan bahwa dalam perjalanan sejarahnya, secara kuantitas Panti Asuhan yang dikelola oleh pemerintah jumlahnya lebih sedikit jika dibandingkan dengan Panti Asuhan yang dikelola oleh pihak swasta atau masyarakat, terutama organisasi keagamaan. Menurut data yang dihimpun oleh organisasi sosial Save The Children, Indonesia menempati urutan kedua sebagai negara dengan jumlah Panti Asuhan terbanyak di dunia. Indonesia itu memiliki Panti Asuhan lebih dari 8.000, itu yang terdaftar di lembaga sosial. Apabila dicari data yang belum terdeteksi dan terdaftar, bisa mencapai 15.000 lebih Panti Asuhan, dan itu bisa menempatkan Indonesia di urutan pertama.

Salah satu organisai keagamaan yang mengambil peran dalam hal ini adalah organisasi Islam Muhammadiyah (Deliar Noer, 1980). Muhammadiyah merupakan suatu gerakan Islam yang mempunyai tugas dakwah Islam dan amar makruf nahi munkar dalam bidang kemasyarakatan. Sudah dengan sendirinya banyak usaha-usaha ditempatkan dalam bidang kemasyarakatan salah satunya 
adalah mendirikan Panti Asuhan baik putra maupun putri untuk menyantuni mereka (Musthafa Kamal Pasha \& Ahmad Adaby Darban, 2000).

Panti Asuhan Muhammadiyah Lhokseumawe ${ }^{1}$ merupakan salah satu Panti Asuhan yang menangkap realitas sosial (terutama bagi anak dan remaja) yang terjadi di dalam masyarakat Aceh, sebagai sebuah peluang untuk membantu masyarakat dengan memberikan perhatian yang lebih komprehensif bagi pendidikan sebagian anak yang belum memiliki kesempatan memperoleh pendidikan sebagaimana mestinya yaitu membantu memberikan pembinaan dan kesempatan menempuh pendidikan bagi anak-anak asuhnya.

Ada fenomena yang menarik jika melesuri napak tilas Panti Asuhan Muhammadiyah Lhokseumawe, terutama ketika berbicara tentang profile anak asuhnya. Dilihat dari background keluarga anak asuh, Panti Asuhan Muhammadiyah Lhokseumawe memiliki anak asuh tidak hanya anak yatim dan piatu dari keluarga fakir dan miskin, namun juga ada yang berasal dari keluarga yang orang tuanya berpisah (cerai) dan dari keluarga yang memiliki anggota keluarganya dalam jumlah yang banyak sehingga tidak mampu diayomi, serta ada yang berasal dari keluarga mantan kombatan GAM (Gerakan Aceh Merdeka).

Dari sisi pemahaman keluarga anak asuh, Panti Asuhan Muhammadiyah Lhokseumawe memiliki anak asuh yang keluarganya memiliki pemahaman berasal dari Muhammadiyah, simpatisan Muhammadiyah, non-Muhammadiyah, bahkan ada yang dari anti Muhammadiyah. Dilihat dari sisi asal daerah, anak asuh tidak hanya berasal dari Kota Lhokseumawe saja, namun ada juga dari daerah lain yang ada di Provinsi Aceh seperti Aceh Utara, Aceh Timur, Bireuen, dan sebagainya. Dilihat dari sisi latar belakang pendidikan, anak asuh pada umumnya mereka belum (sangat minim) mengenal IPTEK dan memahami ilmu keagamaan secara baik, sehingga intensitas kegiatan kedua hal ini tampak dalam perilaku kehidupan mereka di Panti Asuhan.

Bagi anak asuh yang telah menyelesaikan "pendidikan" di Panti Asuhan Muhammadiyah Lhokseumawe, pada umumnya telah memiliki berbagai pengetahuan baik agama maupun umum, sehingga secara "bekal hidup" mereka telah diberikan modal awal dalam meniti kehidupan ini dengan berbagai ketrampilan dan ilmu, yang insya Allah ketika mereka berada di tengah masyarakat bisa dimanfaatkan dengan baik, baik untuk dirinya, keluarganya maupun masyarakat, serta mampu beradaptasi di tengah derasnya era globalisasi.

${ }^{1}$ Didirikan pada tanggal 28 Februari 1968 dengan nama awalnya Badan Penyantun Anak Yatim Muhammadiyah Lhokseumawe. Tempat penampungan awal Anak Yatim bertempat di Perguruan Muhammadiyah, Jln. Teuku Umar No.1, Lancang Garam Lhokseumawe. Pada tahun 1970 Panti Asuhan dipindahkan ke Jln. Darussalam Hagu Selatan di tanah wakaf seorang hamba Allah keturunan Arab yang bernama Syekh Muhammad Al-Kalali. Tanah wakaf tersebut seluas 4192,50 $\mathrm{m}^{2}$ telah didirikan bangunan gedung Panti Asuhan Muhammadiyah Lhokseumawe dengan 2 lantai. (Dokumen Panti Asuhan Muhammadiyah Lhokseumawe). 
Anak asuh yang memiliki prestasi dan akhlak yang baik, menjadi skala prioritas pihak Panti Asuhan Muhammadiyah Lhokseumawe untuk memilih anak asuh tersebut untuk mengikuti pendidikan yang lebih tinggi, baik di daerah sendiri (Aceh) maupun di provinsi lain di Indonesia, bahkan ada yang ke luar negeri (peran Alumni). Untuk dalam negeri perguruan tinggi yang menjadi skala prioritas adalah perguruan tinggi yang berada di bawah perserikatan Muhammadiyah di seluruh Indonesia. Adapun di luar negeri adalah kerjasama alumni yang sedang atau telah menyelesaikan pendidikannya seperti Al-Azhar Mesir, Universitas Khortoum Sudan dan Universitas Islam Antar Bangsa Malaysia.

Berangkat dari fenomena tersebut di atas, maka peneliti tertarik untuk melakukan penelitian tentang organizing sumber daya pengurus panti asuhan Muhammadiyah Lhokseumawe baik dari sisi material maupun non-material dalam pembinaan akhlak anak asuh.

\section{Essensi Organizing}

Organizing merupakan suatu proses menghubungkan orang-orang yang terlibat dalam organisasi tertentu dan menyatupadukan tugas serta fungsinya dalam organisasi. Dalam proses organizing dilakukan pembagian tugas, wewenang, dan tanggung jawab secara terperinci berdasarkan bagian dan bidang masing-masing, sehingga terintegrasikan hubungan-hubungan kerja yang sinergis, kondusif, harmonis, dan seirama dalam mencapai tujuan yang telah disepakati (Saefullah, 2012).

Organizing merupakan pengelompokan kegiatan yang dibutuhkan untuk mencapai tujuan umum organisasi dan penetapan penanggungjawab untuk masing-masing kelompok kegiatan tersebut yang akan berwenang untuk mengawasi kinerja orang-orang yang ada di dalamnya (Leslie W. Rue \& Lioyd L. Byars, 2000).

Agus Wibowo (2013) Pengorganisasian memiliki peranan yang sangat penting, sebab pengorganisasian merupakan penyatuan sumberdaya manusia dan sumberdaya lain dalam sebuah organisasi. Dengan adanya pembidangan tersebut dapat diketahui beberapa manfaatnya, antara lain (1) Antar bidang satu dengan yang lain dapat diketahui batas-batasnya, serta dapat dirancang bagaimana antar bagian dapat melakukan kerjasama sehingga tercapai sinkronisasi tugas, (2) Adanya penugasan yang jelas, menjadikan setiap pegawai atau karyawan mengetahui baik wewenang maupun kewajibannya, dan (3) Dengan digambarkan unit-unit kegiatan dalam sebuah struktur organisasi, dapat diketahui hubungan vertikal dan horizontal, baik dalam jalur struktural maupun fungsional.

Pengorganisasian dalam manajemen merupakan upaya penetapan struktur dan peran dengan cara membuat peta konsep aktivitas yang dibutuhkan untuk mengimplementasikan tujuan yaitu pencapaian target visi dan misi yang 
telah disepakati. Pencapaian target-target tersebut merupakan aktualisasi dari konsep-konsep yang telah direncanakan sebelumnya.

Hikmat (2009), aktivitas mengorganisasikan sesungguhnya merupakan karakter dasar dari sebuah sistem organisasi, yang di dalamnya ada sejumlah orang, baik sebagai manajer maupun sebagai anggota, ada struktur, tujuantujuan, aturan, dan prosedur. Dalam menjalankan tugas organizing, ada beberapa hal yang harus diperhatikan, antara lain (1) Menyediakan fasilitas, perlengkapan, dan staf yang diperlukan untuk melaksanakan rencana, (2) Mengelompokkan dan membagi kerja menjadi struktur organisasi yang teratur, (3) Membentuk struktur kewenangan dan mekanisme koordinasi, (4) Menentukan metode kerja dan prosedurnya, dan (5) Memilih, melatih, dan memberi informasi kepada staf.

Dengan tugas-tugas manajer di atas, maka fungsi pengorganisasian merupakan fungsi strukturalisasi yaitu menetapkan struktur kepegawaian, fungsi relationship yaitu menjalin hubungan dengan pihak eksternal lembaga, dan fungsi integritas yaitu alat untuk mempersatukan usaha-usaha menyelesaikan berbagai kegiatan dalam sebuah organisasi (Hikmat, 2009).

Dalam perspektif Islam, pengorganisasian senantiasa mendorong para pemeluknya untuk melakukan segala sesuatu secara terorganisir dengan rapi, sebab bisa jadi suatu kebenaran yang tidak terorganisir dengan rapi akan dengan mudah bisa diluluhlantakkan oleh kebathilan yang tersusun rapi. Didin dan Hendri menjelaskan bahwa organisasi dalam pandangan Islam bukan sematamata wadah, melainkan lebih menekankan pada bagaimana sebuah pekerjaan dilakukan secara rapi. Organisasi lebih menekankan pada pengaturan mekanisme kerja, dalam sebuah organisasi tentu ada pemimpin dan bawahan (Didin Hafidudin \& Hendri Tanjung, 2003).

Dari beberapa pernyataan di atas dapat disimpulkan bahwa pengorganisasian dilakukan dengan tujuan membagi suatu kegiatan besar menjadi kegiatan-kegiatan yang lebih sederhana. Pengorganisasian mempermudah pimpinan suatu organisasi dalam melakukan aktivitas controlling dan menentukan person yang dibutuhkan untuk melaksanakan job description yang telah ditetapkan. Pengorganisasian bisa laksanakan dengan menentukan aktivitas apa yang harus dikerjakan, siapa yang harus mengerjakannya, bagaimana tugas tersebut diklasifikasikan, siapa yang bertanggung jawab dan pada level mana keputusan atau kebijakan harus diambil.

\section{Hakikat Pembinaan Akhlak}

Kata pembinaan berasal dari bahasa Arab "bina" yang artinya bangunan. Setelah dibekukan ke dalam bahasa Indonesia, jika diberi awalan "pe-" dan akhiran "-an" menjadi "pembinaan" yang mempunyai arti pembaharuan, penyempurnaan usaha, dan tindakan kegiatan yang dilakukan secara berdaya guna dan berhasil guna untuk memperoleh hasil yang baik (Departemen Pendidikan Nasional). 
Adapun secara terminologi, pembinaan merupakan kegiatan yang mengacu pada usaha untuk melaksanakan, mempertaruhkan dan menyempurnakan sesuatu yang telah ada, guna memperoleh hasil yang lebih maksimal (A. Hamid Syarief, 1996). Pembinaan merupakan suatu proses yang membantu individu melalui usaha sendiri dalam rangka menemukan dan mengembangkan kemampuannya agar memperoleh kebahagiaan pribadi dan kemanfaatan sosial (Jumhur \& Muhammad Suryo, 1987).

Dari penjelasan di atas menunjukkan bahwa pembinaan merupakan suatu proses aktivitas yang di lakukan untuk merubah pola pikir dan tingkah laku seseorang serta membentuk karakteristik kepribadiannya, sehingga apa yang diharapkan dapat tercapai sesuai dengan yang dicita-citakan. Dalam suatu pembinaan menunjukkan adanya suatu kemajuan peningkatan, baik dalam aspek intelektual, emosional, spiritual maupun aspek materialnya.

Akhlak merupakan bagian yang tidak dapat dipisahkan dalam kehidupan manusia, sehingga sangat wajar jika pandangan terhadap akhlak sangat bervariasi. Dalam KBBI Akhlak, secara etimologi dapat diartikan sebagai budi pekerti, watak dan tabiat. Menurut Rahmat Djatnika (1994), bahwa kata akhlak berasal dari bahasa Arab (اخلا ق) bentuk jamak dari mufrodnya khuluq (خلق)), yang berarti budi pekerti dan sinonimnya adalah etika dan moral. Adapun secara terminologi, ada beberapa pakar dalam mendefinisikan akhlak, Imam Al-Ghazali (t.t) mengemukakan bahwa akhlak ialah suatu sifat yang tertanam dalam jiwa yang daripadanya timbul perbuatan-perbuatan dengan mudah, dengan tidak memertrlukan pertimbangan pikiran(lebih dahulu). Muhammad bin 'Ilan alSadiqi (1971) mengatakan bahwa akhlak adalah suatu pembawaan yang tertanam dalam diri, yang dapat mendorong (seseorang) berbuat baik dengan gampang.

Berdasarkan pernyataan di atas, dapat disimpulkan bahwa pembinaan akhlak merupakan proses aktivitas penanaman nilai-nilai perilaku budi pekerti dan perilaku baik terhadap Allah swt., sesama manusia, diri sendiri, dan lingkungan sekitarnya yang dilakukan secara berdaya guna dan berhasil guna untuk memperoleh kebahagian hidup di dunia dan akhirat. Akhlak merupakan perilaku yang muncul dari hasil integrasi antara hati nurani, perasaan, pikiran dan pembiasaan yang menyatu dan membentuk suatu kesatuan akhlak yang dihayati dalam kehidupan sehari-hari.

Dalam konsep akhlak segala sesuatu itu dinilai baik dan buruk, terpuji atau tercela, semata-mata berdasarkan kepada Alquran dan Hadis, oleh karena itu dasar dari pembinaan akhlak adalah Alquran dan Hadis. Kedua sumber ajaran Islam tersebut diakui oleh semua umat Islam sebagai dalil naqli yang tinggal mentransfernya dari Allah swt. dan Rasulullah saw. Keduanya hingga sekarang masih terjaga keautentikannya, kecuali Hadis Nabi saw. yang memang dalam perkembangannya banyak ditemukan yang daif atau palsu (Muhammad Azmi, 2006). Melalui kedua sumber inilah dapat dipahami bahwa sifat-sifat 
sabar, qana'ah, senyum, sapa, syukur, dan yang sejenisnya termasuk ke dalam karakteristiik yang baik dan mulia. Sebaliknya, bahwa sifat-sifat seperti hasad, takabur, takabur, riya, merupakan sifat-sifat tercela.

Islam dengan kesempurnaan ajarannya, tidak menolak adanya standar norma lain selain Alquran dan Hadis untuk memahami dan menentukan baik dan buruknya perilaku manusia, selama norma tersebut tidak bertentangan dengan kedua sumber tersebut. Manusia dengan akal dan hati nuraninya dapat juga menentukan standar baik dan buruk, sebab Allah memberikan potensi fitrah kepada manusia berupa tauhid.

Dalam tujuan pembinaan akhlak, dipaparkan beberapa pendapat dari pakar, antara lain menurut Ali Hasan (1988) bahwa tujuan pokok akhlak adalah agar setiap orang berbudi (berakhlak), bertingkah laku (tabiat) berperangai, atau beradat istiadat yang baik sesuai dengan ajaran Islam. Muhammad 'Athiyyah alAbrasyi (2003) menjelaskan tujuan dari pendidikan moral dan akhlak dalam Islam adalah membentuk orang-orang yang bermoral baik, keras kemauan, sopan dalam bicara dan mulia dalam bertingkah laku dan perangai, bersifat bijaksana, sempurna, sopan dan beradab, ikhlas, jujur dan suci. jiwa dari pendidikan Islam adalah pendidikan moral dan akhlak. Upaya pembinaan akhlak anak tidak hanya dibebankan kepada tokoh spiritual (agama), dengan kata lain bukan hanya tugas guru agama semata, melainkan tugas semua anggota masyarakat. Karena ada paradigma yang muncul pada sebagian masyarakat bahwa pembinaan akhlak hanya menjadi kewajiban tokoh spiritual (agama), sehingga sebagian masyarakat berlepas diri dengan fenomena degradasi perilaku moral yang terjadi di tengah kehidupan masyrakat.

Zainuddin (1999) menjelaskan bahwa secara umum pembagian akhlak berdasarkan sifatnya dibagi menjadi dua, yaitu akhlak mulia (akhlakmahmudah) dan akhlak tercela (akhlakmadzmumah). Akhlak mulia adalah yang harus kita terapkan dalam kehidupan sehari-hari, sedang akhlak tercela adalah akhlak yang harus kita jauhi jangan sampai kita praktikkan dalam kehidupan kita sehari-hari. Sedangkan pembagian akhlak berdasarkan obyeknya dibedakan menjadi dua yaitu: yaitu akhlak kepada sang Khaliq dan akhlak kepada makhluq.

Kajian atau ruang lingkup akhlak adalah tingkah laku manusia, atau tepatnya nilai dari tingkah lakunya, yang bisa bernilai baik (mulia) atau sebaliknya bernilai buruk (tercela) kepada Khaliq (Allah Sang Pencipta) dan kepada makhluq (ciptaan-Nya) (Marzuki, 2009). Mengkaji dan mendalami konsep dan ruang lingkup pembinaan akhlak merupakan wasilah (perantara) yang bisa mengantarkan manusia untuk dapat mengimplementasikan akhlak mulia seperti yang telah disyariatkan oleh Allah swt. dan Rasulullah saw. Pemahaman yang jelas secara totalitas tentang konsep dan ruang lingkup akhlak, akan memiliki landasan atau dasar pijakan serta pedoman untuk mengarahkan perilaku manusia dalam kehidupannya sehari-hari, sehingga dapat dipahami apakah yang manusia 
implementasikan termasuk akhlak mahmudah (mulia) atau akhlak madzmumah (tercela).

\section{Kedudukan Anak Asuh dan Panti Asuhan}

\section{Anak Asuh}

Dalam pasal 1 Undang-Undang RI No. 23 Tahun 2002 tentang Perlindungan Anak, disebutkan tentang status dan pembagian anak antara lain pada point (1) Anak adalah seseorang yang belum berusia 18 tahun, termasuk anak yang masih dalam kandungan, dan pada point (5) Anak asuh adalah anak yang diasuh oleh seseorang atau lembaga, untuk diberikan bimbingan, pemeliharaan, perawatan, pendidikan, dan kesehatan, karena orang tuanya atau salah satu orang tuanya tidak mampu menjamin tumbuh kembang anak secara wajar. Sedangkan pengertian asuh adalah menjaga (merawat dan mendidik) anak kecil, membimbing (membantu, melatih, dan sebagainya) supaya dapat berdiri sendiri (Departemen Pendidikan Nasional, 2005).

Dapat disimpulkan bahwa anak asuh adalah anak yang berasal dari keluarga kurang mampu atau keluarga yang tidak memiliki kemampuan untuk membiayai kehidupan anak untuk diberikan bimbingan, perawatan, kesehatan, pendidikan, serta kebutuhan lainnya baik fisik maupun nonfisik, kemudian diserahkan kepada pihak lain baik secara perorangan maupun lembaga atau yayasan dan usia anak tersebut belum mencapai 18 tahun (masih dalam usia pendidikan) atau belum pernah menikah.

\section{Panti Asuhan}

Panti Asuhan terdiri dari dua kata yaitu Panti dan Asuban. Panti Asuhan apabila ditelaah secara etimilogi berasal dari dua kata, yaitu "panti" yang berarti rumah atau tempat kediaman. Sedangkan asuhan dalam KBBI adalah bimbingan, didikan. Panti Asuhan adalah tempat merawat anak-anak yatim atau yatim piatu, anak-anak terlantar.

Menurut PP Republik Indonesia Nomor 2 tahun 1988 Pasal 1 ayat 6, pengertian Panti dinyatakan sebagai berikut: Panti adalah lembaga atau kesatuan kerja yang merupakan sarana dan prasarana yang memberikan pelayanan sosial dengan berdasarkan profesi kerja sosial. Asuhan adalah berbagai upaya yang dilakukan kepada anak yang tidak mempunyai orang tua dan terlantar, anak terlantar, dan anak yang mengalami kelakuan yang bersifat semnetara sebagai pengganti orang tua atau keluarga agar dapat tumbuh dan berkembang dengan wajar baik secara jasmani, rohani, maupun sosial (Tim Redaksi Pustaka Yustisia, 2010).

Sedangkan secara terminologi, ada beberapa pakar dalam menjelaskan pengertian Panti Asuhan, antara lain menurut W.J.S. Purwadarminta, mengatakan bahwa Panti Asuhan adalah tempat atau rumah untuk memelihara atau merawat dan mendidik anak-anak yatim atau piatu. Menurut Badan Pembinaan Kondisi dan Pengawasan Kegiatan (1982), Panti Asuhan dapat 
diartikan sebagai suatu lembaga untuk mengasuh anak-anak, menjaga dan memberikan bimbingan dari pimpinan kepada anak dengan tujuan agar mereka dapat menjadi manusia dewasa yang cakap dan berguna serta bertanggung jawab terhadap dirinya dan terhadap masyarakat kelak dikemudian hari. Panti Asuhan dapat pula dikatakan atau berfungsi sebagai pengganti keluarga dan pimpinan Panti Asuhan sebagai pengganti orang tua.

Berdasarkan pemahaman di atas, maka Panti Asuhan merupakan suatu institusi kesejahteraan sosial yang berperan memberikan "pelayanan pengganti" keluarga dalam pemenuhan kebutuhan materi, fisik, mental, dan sosial pada anak asuh, sehingga mendapatkan kesempatan yang sama seperti anak yang lainnya serta perkembangan kepribadiannya sesuai dengan yang diharapkan.

Keberadaan Panti Asuhan tentunya harus memiliki dasar atau landasan hukum yang kuat, sehingga Panti Asuhan keberadaannya betul-betul merupakan salah satu wahana atau media untuk mengatasi kendala-kendala sosial. Adapun dasar atau landasan Panti Asuhan antara lain:

a. Dasar yuridis/hukum formal, adapun dasar yuridis formal tersebut adalah dasar ideologi, yakni dasar yang bersumber dari Filsafat Negara yaitu Pancasila, terutama sila kelima. Dasar konstitusional, yaitu dasar dari undangundang yang sedang berlaku, yaitu UUD 1945, sebagaimana tercantum pada bab XIV pasal 34. Dasar operasional, yaitu adalah dasar secara langsung mengatur pelaksanaan tentang pelayanan kesejahteraan sosial di Indonesia, diantaranya UU No.23Tahun 2002 tentang PerlindunganAnak, UU No. 11 Tahun 2009 tentang Kesejahteraan Sosial, dan UU No. 4 Tahun 1979 tentang Kesejahteraan Anak.

b. Dasar Religius, surat al-Ma'un ayat 1-3: Tabukah kamu (orang) yang mendustakan agama?, Itulah orang yang menghardik anak yatim, dan tidake menganjurkan memberi Makan orang miskin. Ibnu Katsir (2004) menafsiri ayat tersebut, bahwa "Tahukah kamu (orang) yang mendustakan agama?", yakni apakah kamu tahu, hai Muhammad, orang yang telah mendustakan adDin, yaitu hari kebangkitan serta pemberian balassan dan pahala?" "Itulah orang yang menghardik anak yatim", yakni orang yang berbuat sewenangwenang terhadap anak yatim dan menzalimi haknya, tidak memberinya makan serta tidak juga berbuat baik kepadanya. "Dan tidak menganjurkan memberi makan orang miskin", yakni orang faqir yang tidak memilki apapun untuk memenuhi dan mencukupi kebutuhannya.

Selanjutnya, berbicara perihal tujuan Panti Asuhan tidak terlepas dari pembahasan tujuan kesejahteraan sosial Panti Asuhan dan juga merupakan salah satu bidang cakupan pelayanaan sosial, perlu dikembangkan melalui upaya (1) Pemberian bimbingan dan bantuan seperti: peningkatan daya bimbingan prilaku kehidupan beragama dan perilaku terpuji, peningkatan daya cipta dan penumbuhan kesadaran akan hidup sehat dan hidup bermasyarakat, (2) 
Meningkatkan kemauan dan kemampuan untuk menolong dirinya sendiri guna memperbaiki dan meningkatkan taraf kesejahteraan sosial, dan (3) Pengembangan dan penyuluhan sosial untuk meningkatkan harkat dan martabat kemanusiaan dan gotong royong ((Tim Sosiologi, 2004).

Maksud dari pendirian Panti Asuhan adalah untuk membantu dan sekaligus sebagai orang tua pengganti bagi anak yang terlantar maupun yang orang tuanya telah meninggal dunia untuk memberikan rasa aman secara lahir batin, memberikan kasih sayang, dan memberikan santunan bagi kehidupan mereka. Tujuannya adalah untuk mengantarkan mereka agar menjadi manusia yang dapat menolong dirinya sendiri, tidak bergantung pada orang lain dan bermanfaat bagi masyarakat (Tim Sosiologi, 2004).

Berdasarkan tujuan di atas dapat disimpulkan bahwa tujuan didirikannya lembaga Panti Asuhan adalah unruk memberikan layanan kesejahteraan pada anak yatim, yatim piatu, dan terlantar secara baik menyangkut tentang seluruh aspek kehidupan, baik jasmani maupun rohani agar anak asuh yang berada di Panti Asuhan dapat berkembang dengan baik dan memiliki karakteristik kepribadian yang sempurna.

\section{Metode Penelitian}

Penelitian ini merupakan penelitian kualitatif dengan menggunakan pendekatan fenomenologi. Sumber data lapangan berwujud dalam data primer dan data skunder. Analisis data yang digunakan adalah analisis deskriptif kualitatif. Teknik analisis data terdiri dari reduksi data, penyajian data, dan kesimpulan. Adapun pemeriksaan keabsahan data terdiri dari credibility, transferability, dependability, dan confirmability.

\section{Hasil Penelitian}

Berangkat dari rumusan masalah diatas, maka berikut ini adalah hasil penelitian yang dapat digambarkan dalam beberapa poin berikut ini :

\section{Organizing Sumber Daya Panti Asuhan dalam Pembinaan Akhlak Anak} Asuh

Panti Asuhan Muhammadiyah Lhokseumawe sebagaimana Panti Asuhan pada umumnya, memiliki sumber daya operasional yang telah didesain secara sistematis untuk mencapai visi dan misi secara efektif dan efesien. Pada bagian ini, penulis akan memaparkan bagaimana organizing sumber daya lembaga yang mendukung untuk membentuk atau membina akhlak anak asuh, dimana organizing sumber dayanya disesuaikan dengan susunan kepengurusan atau struktur lembaga, antara lain:

\section{1) Ketua}

Panti Asuhan Muhammadiyah Lhokseumawe merupakan sebuah lembaga atau organisasi yang memiliki manajemen secara sistematis. Dalam menjalankan operasionalnya, lembaga memilki Ketua yang bertanggung jawab terhadap seluruh aktivitasnya. Adapun yang berhubungan dengan pembinaan akhlak anak 
asuh, Ketua Panti Asuhan hanya sebagai pengawas dan pengambil kebijakan secara makro, adapun yang bersifat teknis telah dipercayakan kepada bagian Pengasuhan. Sebagaimana penjelasan M. Adam Sulaiman selaku Ketua Panti Asuhan bahwa:

Saya sebagai Ketua Panti Asuhan, dalam masalah pembinaan akhlak anak asuh, secara teknis saya percayakan sepenuhnya kepada bagian Pengasuhan, karena bidang ini merupakan bidang yang selalu bersentuhan dengan anak asuh. Saya hanya berperan sebagai pengawas dari semua kegiatan yang ada di Panti Asuhan, jika ada laporan bahwa ada anak asuh yang tidak bisa dibina lagi, maka status anak asuh ini menjadi tanggungjawab atau kebijakan saya, apakah dikeluarkan atau ada kebijakan lain.

Hasil observasi di kantor Panti Asuhan, Ketua melakukan koordinasi dengan bidang-bidang yang telah dibentuk dan mengevaluasi sejauh mana kinerjanya dalam rentang waktu tertentu. Dalam masalah pembinaan akhlak anak asuh, secara teknis dipercayakan sepenuhnya kepada bagian Pengasuhan, karena bidang ini merupakan bidang yang selalu bersentuhan dengan anak asuh. Ketua hanya berperan sebagai pengawas dari semua kegiatan yang ada, serta sebagai pengambil kebijakan terakhir jika ada laporan bahwa ada anak asuh yang tidak bisa dibina lagi, apakah dikeluarkan atau ada kebijakan lain.

Ketua Panti Asuhan dalam menjalankan fungsinya secara global terbagi menjadi dua yakni fungsi secara internal dan fungsi secara eksternal. Dimana fungsi internal, melakukan koordinasi dengan bidang-bidang yang telah dibentuk dan mengevaluasi sejauh mana kinerjanya dalam rentang waktu tertentu. Sedangkan yang bersifat eksternal, melakukan kerjasama dengan berbagai stakeholder, baik pemerintah maupun nonpemerintah dalam rangka untuk mendukung berbagai macam program atau kegiatan dilaksanakan di Panti Asuhan.

\section{2) Sekretaris}

Manajemen sekretaris Panti Asuhan Muhammadiyah Lhokseumawe merupakan suatu proses kegiatan mengelola dan mengatur semua aktivitas yang berhubungan langsung maupun tidak langsung dengan kegiatan Pimpinan untuk kelancaran operasional Panti Asuhan. Dalam pembinaan akhlak anak asuh, sekretaris tidak terlibat langsung secara praktis di lapangan, Lizan Abbas sebagai sekretaris Panti Asuhan menjelaskan bahwa:

Untuk pembinaan akhlak anak asuh, saya tidak terlibat langsung dalam kegiatan mereka, kegiatan ini ditangani sepenuhnya oleh bidang Pengasuhan. Khusus dalam masalah anak asuh, saya hanya membuat, mencatat, dan mengarsipkan seluruh surat menyurat yang berhubungan 
dengan lembaga dan kegiatan yang ada di dalamnya, mulai dari mereka masuk sampai mereka selesai "pendidikannya" di Panti Asuhan.

Hasil observasi di kantor Panti Asuhan, kehadiran sekretaris ke lembaga tidak terikat dengan jam dinas, akan tetapi dalam setiap harinya sekretaris menyempatkan diri untuk masuk sekitar satu atau dua jam. Dalam kegiatan hariannya, sekretaris membuat, mencatat dan mengarsipkan hal-hal yang berhubungan dengan surat menyurat, baik yang sifatnya individu anak asuh maupun kegiatan/program anak asuh selama berada di Panti Asuhan. Di samping itu pula, sekretaris mengurus segala administrasi perkantoran yang berhubungan dengan beberapa stakeholder, baik dari lembaga pemerintah maupun swasta. Sekretaris tidak bersinggungan langsung dengan kegiatan pembinaan akhlak asuh, dalam hal ini dipercayakan sepenuhnya kepada bidang Pengasuhan.

Untuk kelancaran administrasi dalam menjalankan operasionalnya, pekerjaan sekretaris Panti Asuhan adalah membantu pimpinan agar dapat melaksanakan tugasnya secara efektif dan efisien, dan sekretaris merupakan jabatan yang dituntut memiliki profesionalitas, karena lembaga yang dimenejnya merupakan lembaga yang bergerak dalam berbagai dimensi. Dalam pembinaan akhlak anak asuh, sekretaris tidak terlibat langsung secara praktis di lapangan. Masalah anak asuh, sekretaris hanya berperan dalam membuat, mencatat, dan mengarsipkan seluruh surat menyurat yang berhubungan dengan lembaga dan kegiatan yang ada di dalamnya, dari mereka masuk sampai mereka selesai "pendidikannya" di Panti Asuhan, yang selanjutnya semua kegiatan pembinaan akhlak dipercayakan kepada bidang Pengasuhan.

\section{3) Bendahara/Bidang Dana, Konsumsi, dan Akomodasi}

Sejak keberadaannya pada tahun 1968, sumber keuangan Panti Asuhan Muhammadiyah Lhokseumawe untuk operasionalnya didapatkan dari beberapa elemen masyarakat dan stakeholder, sebagaimana penjelasan M. Adam Sulaiaman bahwa:

Sumber keuangan selama ini, kami dapatkan dari berbagai elemen, antara lain dari pihak pemerintah, perorangan, maupun lembaga/organisasi, dan dari usaha ekonomi produktif Panti Asuhan. Sumber keuangan yang kami dapatkan, ada yang sifatnya rutin dan insidentil. Rutin dalam artian sampai dengan sekarang masih berlanjut bantuannya, sedangkan insidentil bantuannya tidak mengikat, terkadang ada, terkadang tidak, bahkan ada yang tidak ada lagi.

Koneksitas antara bendahara/bidang dana, konsumsi, dan akomodasi dalam kegiatan pembinaan akhlak anak asuh di Panti Asuhan, tidak terlibat 
secara langsung, sebagaimana yang diutarakan oleh Zulkhairi sebagai bendahara Panti Asuhan, bahwa:

Untuk pembinaan akhlak anak asuh di Panti Asuhan, kami yang membidangi bagian keuangan hanya berfungsi menyediakan anggaran untuk membeli kebutuhan anak asuh, agar mereka bisa mengikuti seluruh program atau kegiatan yang telah diwajibkan, sedangkan aplikasi ditangani oleh bidang Pengasuhan. Anggaran yang kami keluarkan setiap harinya atau dalam waktu tetentu, disesuaikan dengan laporan dari bidang Pengasuhan terhadap kebutuhan anak.

Hasil telaah dokumentasi di kantor Panti Asuhan, sumber keuangan dan operasional bantuan bersifat tidak mengikat, ada yang sifatnya insidentil dan ada juga yang bersifat periodik seperti berjangka waktu bulanan dan berjangka waktu tahunan. Namun dari kesemuanya itu, sampai dengan sekarang ada yang masih aktif dan ada pula yang sudah tidak aktif lagi. Hal ini disebabkan karena kondisi stakeholder yang tidak memungkinkan lagi untuk menjadi donatur tetap. Jangka waktu tertentu, bidang keuangan melakukan pengecekan kebutuhan operasional lembaga, biasanya dalam seminggu sekali, yakni pada hari ahad. Di samping itu, sumber keuangan Panti Asuhan berasal dari usaha ekonomi produktif, seperti usaha pangkas rambut, penggemukan sapi, dan sewa gedung/toko. Bidang keuangan dan bendahara tidak terlibat langsung dalam kegiatan atau program pembinaan anak asuh. Untuk kebutuhan anak asuh, baik materi atau non-materi, anggaran yang dikeluarkan disesuaikan dengan laporan dari bidang Pengasuhan.

Sumber keuangan Panti Asuhan berasal dari keluarga besar Muhammadiyah, baik dari pengurus pusat, wilayah, maupun daerah. Kemudian dari simpatisan masyarakat baik perorangan maupun lembaga, perusahaan proyek vital yang ada di sekitar kabupaten Aceh Utara dan Kota Lhokseumawe, dari pemerintah (dinas sosial pusat dan daerah), serta dari usaha ekonomi produktif. Sampai dengan sekarang ada yang masih aktif dan ada pula yang sudah tidak aktif lagi. Dari sumber dan aplikasi keuangan yang ditangani oleh bidang keuangan sangat mendukung untuk pembinaan akhlak dalam memenuhi kebutuhan anak asuh baik yang sifatnya material maupun nonmaterial. Pembinaan akhlak anak asuh yang ditangani oleh bidang Pengasuhan koordinasi dengan bidang keuangan dengan melaporkan besaran anggaran yang dibutuhkan dalam menjalankan berbagai program atau kegiatan di Panti Asuhan kepada bagian keuangan.

\section{4) Bidang Pendidikan, Pengawasan, dan Ketertiban}

Untuk penanganan sistem pendidikan, pengawasan, dan ketertiban di Panti Asuhan Muhammadiyah Lhokseumawe, bidang ini hanya sebatas sebagai konseptor dan pengawasan, serta menjalin kerjasama dengan pihak ketiga. Sebagaimana yang diutarakan oleh M. Adam Sulaiman bahwa: 
Bidang pendidikan, pengawasan dan ketertiban tidak hanya menangani pendidikan formal saja (sekolah) namun pendidikan nonformal (kajian keagamaan di Panti Asuhan). Penanganan pendidikan terhadap anak asuh di Panti Asuhan tidak hanya meliputi kebutuhan yang bersifat fisik saja, namun juga meliputi kebutuhan nonfisik, seperti kajian keagamaan, keMuhammadiyahan, pelatihan, dan lain sebagainya yang dipercayakan sepenuhnya pada bidang Pengasuhan. Sedangkan untuk penanganan pengawasan dan ketertiban di Panti Asuhan, kita melakukan kerjasama dengan beberapa pihak.

Hasil observasi di komplek Panti Asuhan, pengembangan pendidikan formal anak asuh, diarahkan untuk melanjutkan pendidikannya sesuai dengan jenjang yang telah di tentukan oleh Pengasuh. Arahan yang dilakukan oleh pihak lembaga disesuaikan dengan ijazah atau rapor ketika mereka mengajukan diri untuk menjadi anak asuh Panti Asuhan. Setiap anak asuh diwajibkan untuk mengikuti semua kegiatan, baik pendidikan formal (sekolah) maupun nonformal (Panti Asuhan). Untuk pendidikan formal (sekolah), setiap harinya (kecuali hari libur) anak asuh berangkat sekolah dengan jarak tempuh sekitar $1 \mathrm{~km}$, yang berada di desa Lancang Garam. Sedangkan kegiatan nonformal yakni proses belajar mengajar di Panti Asuhan, baik yang intra maupun ekstrakurikuler terjadi setiap harinya.

Berikut lembaga pendidikan formal anak asuh Panti Asuhan Muhammadiyah Lhokseumawe yang disesuaikan dengan kelompok usia dan kategorisasi sekolah:

\begin{tabular}{ccl}
\hline No. & Kelompok Usia & \multicolumn{1}{c}{ Kategorisasi Sekolah } \\
\hline 1. & $8-12$ & SD Muhammadiyah Lhokseumawe \\
\hline 2. & $13-15$ & $\begin{array}{l}\text { SMP Muhammadiyah Lhokseumawe } \\
\text { MTsS Muhammadiyah Lhokseumawe } \\
\end{array}$ \\
& & MTsS Ihyaaussunnah Muhammadiyah \\
\hline 3. & $16-18$ & $\begin{array}{l}\text { SMA Muhammadiyah Lhokseumawe } \\
\text { MA Ihyaaussunnah Muhammadiyah }\end{array}$ \\
\hline
\end{tabular}

\section{Tabel 1.}

Data lembaga pendidikan formal sesuai dengan kelompok usia

Dari tabel di atas menunjukkan bahwa, penempatan anak asuh pada lembaga pendidikan formal disesuaikan dengan klasifikasi umur, dan semuanya berada pada lembaga pendidikan di bawah Majelis Dikdasmen Muhammadiyah Kota Lhokseumawe.

Bidang pendidikan, pengawasan, dan ketertiban, tidak hanya menangani pendidikan formal saja (sekolah) namun pendidikan nonformal (kajian 
keagamaan di Panti Asuhan). Dalam pembinaan akhlak anak asuh di Panti Asuhan hanya berperan sebatas konseptor dan pengawasan, serta menjalin kerjasama dengan pihak ketiga, sedangkan eksekutornya di lapangan dilimpahkan pada bidang Pengasuhan. Bidang pendidikan, pengawasan, dan ketertiban dalam membuat programnya terlebih dahulu dimusyawarahkan dengan pengurus lain, agar tidak berbenturan program, dengan harapan programnya bisa dilaksanakan secara efektif dan efisien. Untuk penanganan pengawasan dan ketertiban, dari pihak Panti Asuhan melakukan kerjasama dengan beberapa pihak, jika yang sifatnya internal lembaga, maka ditangani sepenuhnya sesuai dengan aturan yang berlaku secara internal, namun jika yang sifatnya eksternal, maka bekerjasama dengan beberapa stakebolder dan pihak keamanan (TNI dan POLRI).

\section{5) Bidang Kesehatan dan Kebersihan}

Anak asuh di Panti Asuhan Muhammadiyah Lhokseumawe, baik tingkat Sekolah Dasar (SD), Sekolah Menengah Pertama (SMP), dan Sekolah Menengah Atas (SMA), dalam usia periode ini didapatkan banyak permasalahan kesehatan yang sangat menentukan kualitas anak asuh, baik yang sifatnya fisik maupun nonfisik. Dalam pembinaan akhlak anak asuh, bidang kesehatan dan kebersihan hanya menangani fisik anak asuh agar mampu mengikuti program atau kegiatan yang dibebankan kepada mereka. Musmuliadi sebagai tenaga medis Panti Asuhan, menjelaskan bahwa:

Secara langsung dalam pembinaan akhlak anak asuh, kami tidak terlibat, namun secara tidak langsung kami telah membantu bidang Pengasuhan agar anak asuh dapat mengikuti seluruh program atau kegiatan yang telah diwajibkan terhadap mereka yakni dengan menjaga kesehatan fisiknya. Pada umumnya anak asuh yang masuk ke Panti Asuhan, memiliki riwayat kesehatan yang sangat variatif. Untuk proses penyembuhan dan proses pencegahan, maka kami selalu melakukan pemantauan terhadap kesehatan mereka secara berkala.

Hasil observasi di asrama Panti Asuhan, untuk menjaga kesehatan anak asuh, diberlakukan piket harian kepada anak asuh, ada yang membersihkan halaman, ruang makan, dan musala, adapun kamar tidur menjadi kewajiban setiap individu anak asuh, dan semuanya ini dilakukan setiap harinya diwaktu pagi sebelum sarapan dan berangkat sekolah. Dalam jangka waktu tertentu, bidang kesehatan dan kebersihan melakukan crosscbek kebersihan dalam kamar anak asuh, serta di tempat-tempat fasilitas yang sering dimanfaatkan setiap harinya, seperti kamar mandi, ruang makan, musala, dan halaman.

Dalam menangani kesehatan anak asuh, jenis penyakit atau sakit hanya dalam skala kecil atau yang sifatnya insidentil (sementara) saja. Jika penyakit atau sakitnya di luar kemampuan bidang kesehatan, maka untuk penanganannya akan 
dirujuk ke Rumah Sakit yang ada di seputar Kota Lhokseumawe. Dalam pembinaan akhlak anak asuh, bidang kesehatan tidak terlibat secara langsung, namun membantu bidang Pengasuhan agar anak asuh dapat mengikuti seluruh program atau kegiatan yang telah diwajibkan terhadap mereka yakni dengan menjaga kesehatan fisiknya. Di sela-sela dalam menangani kesehatan anak asuh, bidang kesehatan dan kebersihan juga memberikan arahan serta bimbingan tentang keutamaan menjaga kesehatan, baik dari sisi pribadi (fisik dan spiritual) anak asuh maupun lingkungannya, walaupun terkadang harus menggunakan bahasa atau nada nasehatnya yang sedikit "lebih tinggi".

\section{6) Bidang Pengasuhan}

Pengasuhan di Panti Asuhan Muhammadiyah Lhokseumawe merupakan proses aktivitas interaksi dan aksi antara pengasuh dan anak asuh dalam memberikan pengetahuan dan pengalaman secara sosial, emosional, dan intelektual sebagai bekal dan panduan kehidupan anak asuh menuju kedewasaan. Bidang Pengasuhan merupakan bidang yang sangat vital dalam penentuan arah dan tujuan pembinaan akhlak anak asuh. Dalam pembinaan akhlak asuh telah menjadi tanggung jawab bidang Pengasuhan secara menyeluruh, baik secara teoritis maupun secara praktis. Sebagaimana yang dikemukakan oleh Saifuddin Abbas sebagai Pengasuhan, bahwa:

Kami selaku yang membidangi Pengasuhan telah dipercayakan secara praktis terhadap pembinaan akhlak asuh di Panti Asuhan. Kami menjalankan semua program dan kegiatannya sesuai dengan konsep atau kebijakan yang telah disepakati oleh seluruh pengurus. Hal ini sangat penting sekali karena konsep atau kebijakan yang telah disepakati menjadi pedoman kami dalam menjalankannya di lapangan, sehingga tidak akan terjadi yang namanya tumpang tindih program atau kesalahan. Kami selalu berkoordinasi dengan bidang-bidang lain jika dalam pelaksanaanya terjadi benturan-benturan yang tidak dapat kami selesaikan secara internal Pengasuhan, terutama dengan Ketua Panti Asuhan dan bidang pendidikan, sehingga kebijakan kami di lapangan dapat dipertanggungjwabkan.

Hasil observasi di asrama, lapangan olah raga, dan musala Panti Asuhan, mulai dari pagi hari, Pengasuh telah membangunkan anak asuh untuk salat subuh berjamaah di musala, yang selanjutnya diikuti dengan kegiatan bimbingan tausiyah singkat dan hafalan Alquran menjelang mandi dan sarapan pagi. Menjelang anak asuh berangkat sekolah, Pengasuh mengumpulkan mereka sambil memberikan uang jajan sekolah, juga menanyakan bagaimana perkembangan pendidikan formalnya.

Pada siang hari, yakni waktu zuhur, setelah anak asuh kembali dari sekolahnya masing-masing, Pengasuh mulai berinteraksi kembali dengan anak 
asuh, yakni memerintahkan anak asuh bagi yang belum salat zuhur, setelah itu mereka dipersilahkan secara bersama-sama untuk makan siang bersama serta untuk istirahat siang sampai menjelang waktu salat asar. Setelah salat asar, Pengasuh memulai kegiatannya dengan bimbingan hafalan Alquran sekitar 30 menit, setelah itu anak asuh bersama Pengasuh mengikuti kegiatan oleh raga bersama sampai menjelang waktu makan sore dan selanjutnya mandi. Kemudian melaksanakan salat magrib secara berjamaah serta mengikuti intrakurikuler Panti Asuhan sesuai dengan jadwal yang telah ditentukan. Kegiatan ini dilaksanakan menjelang salat isya, dan setelahnya anak asuh dibimbing untuk menyelesaikan tugas atau mengulangi materi dari sekolah masing-masing, sampai menjelang istirahat malam

Dalam melaksanakan pembinaan akhlak asuh, Pengasuh hanya menjalankan konsep atau kebijakan yang telah disepakati dalam musyawarah pengurus, sehingga dalam pelaksanannya bidang Pengasuhan hanya mengikuti format yang telah digariskan. Walaupun demikian ada bagian-bagian tertentu yang sifatnya teknis dan insidentil, bidang Pengasuhan langsung mengambil kebijakan di lapangan selama kebijakan tersebut tidak bertentangan dengan frame yang telah disepakati oleh pengurus lembaga.

\section{Diskusi Hasil Penelitian}

Hasil temuan pengaturan sumber daya Panti Asuhan Muhammadiyah Lhokseumawe dalam pembinaan akhlak anak asuh di atas, menunjukkan bahwa dalam menjalankan roda organisasinya, Panti Asuhan Muhammadiyah Lhokseumawe sebagaimana Panti Asuhan pada umumnya, memiliki sumber daya operasional (departemen) yang telah didesain secara sistematis. Dalam konteks pembinaan akhlak anak asuh, departementalisasi (membagi pekerjaan berdasarkan pembagian wilayah dan wewenang kerja) saling berkoordinasi antara satu bidang dengan bidang yang lain untuk mewujudkan visi dan misi secara efektif dan efesien. Pengaturan sumber daya di Panti Asuhan merupakan usaha penciptaan hubungan tugas yang jelas antara personalia, sehingga dengan demikian setiap pengurus dapat bekerja bersama-sama dalam kondisi yang baik untuk mencapai visi dan misi dari lembaga.

Dalam menjalankan tugas organizing, pengaturan sumber daya Panti Asuhan telah memperhatikan beberapa hal, sebagaimana yang diutarakan oleh Hikmat (2009), yaitu (1) Menyediakan fasilitas, perlengkapan, dan staf yang diperlukan untuk melaksanakan rencana, (2) Mengelompokkan kerja menjadi struktur organisasi yang teratur, (3) Membentuk struktur kewenangan dan mekanisme koordinasi, (4) Menentukan metode kerja dan prosedurnya, dan (5) Memilih, melatih, dan memberi informasi kepada staf.

Pengaturan sumber daya di Panti Asuhan merupakan langkah-langkah operasional dan fungsional organisasi meliputi usaha-usaha departementalisasi yang akan menentukan spesialisasi orang-orang dalam kegiatan organisasi secara 
keseluruhan, termasuk di dalamnya proses kerja sama yang kuat, pendelegasian wewenang dan tanggung jawab, penentuan orang-orang yang akan melakukan pekerjaan, pola koordinasi yang akan dibangun, dan semacamnya. Sebagaimana yang dikemukakan oleh Nanang Fatah (2008), bahwa pengorganisasian sebagai proses membagi kerja ke dalam tugas-tugas yang lebih kecil, membebankan tugas-tugas itu kepada orang yang sesuai dengan kemampuannya, dan mengalokasikan sumber daya, serta mengkoordinasikannya dalam rangka efektivitas pencapaian tujuan organisasi.

Pengaturan sumber daya yang telah dijalankan oleh Panti Asuhan, sesuai dengan fungsi pengorganisasian yang dikemukakan oleh Burhanuddin (1994), yaitu (1) Mengatur tugas dan kegiatan kerjasama dengan sebaik-baiknya, (2) Mencegah kelambatan kerja dan kesulitan yang dihadapi, (3) Mencegah kesimpangsiuran kerja, dan (4) Menentukan pedoman-pedoman kerja.

Disetiap organisasi posisi dan peran pimpinan selalu sangat sentral dan menentukan. Berkembang atau tidaknya sebuah organisasi sangat tergantung pada sejauh mana pimpinan mampu mengelola semua potensi personalia, materil dan non-materil yang ada untuk memajukan organisasinya. Demikian pula halnya dengan Panti Asuhan sebagai sebuah organisasi sosial, maka posisi ketua Panti Asuhan juga sangat menetukan dalam memajukan serta mengembangkan lembaga yang dikelola atau dipimpinnya. Pimpinan Panti Asuhan memiliki otoritas yang menentukan perkembangan lembaganya, karena kedudukannya sangat strategis karena berhubungan langsung dengan tindakan kebijakan yang dirumuskan dan ditetapkan untuk diaplikasikan secara operasional oleh seluruh personalia bawahannya.

Pimpinan Panti Asuhan bersama pengurus Daerah Muhammadiyah Lhokseumawe telah melaksanakan kegiatan pengaturan sumber daya di lembaga ini dengan kemampuan profesionalismenya untuk menentukan siapa saja yang akan melaksanakan tugas sesuai dengan tupoksi dan prinsip pengorganisasian. Dalam pengaturan sumber daya, Pimpinan Panti Asuhan bukan hanya mengidentifikasikan jabatan dan menentukan hubungan antar komponen dalam lembaga, namun juga sangat menekankan pentingnya pertimbangan yang cermat terhadap personalia yang akan menangani suatu bidang.

Pengaturan sumber daya yang dilakukan pihak Panti Asuhan, sesuai dengan firman Allah swt. dalam surat al-An'am ayat 165 :

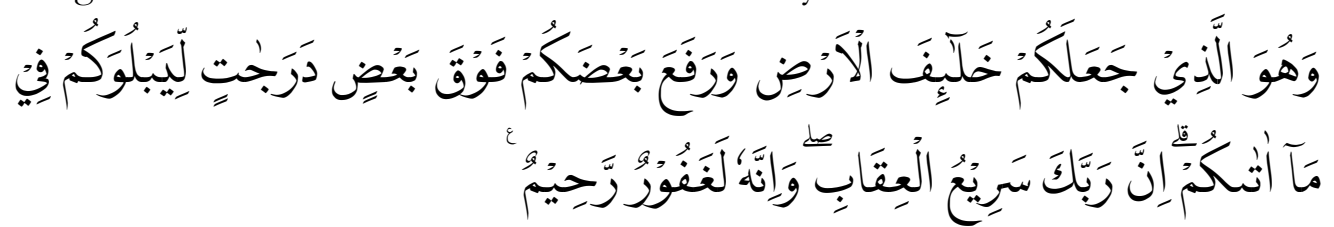

Dan Dialah yang menjadikan kamu sebagai khalifah-khalifah di bumi dan Dia mengangkat (derajat) sebagian kamu di atas yang lain, untuk mengujimu atas 
(karunia) yang diberikan-Nya kepadamu. Sesunggubnya Tuhanmu sangat cepat memberi hukuman dan sungguh, Dia Maha Pengampun, Maha Penyayang. (Q.S. Al-An'am : 165).

Ayat ini mengandung suatu dorong kepada kaum mukminin agar tetap memelihara sifat-sifat utama (akblak al-karimab) dan agar mereka tetap mempunyai semangat yang tinggi. Umat yang paling baik di dunia adalah umat yang mempunyai dua macam sifat, yaitu mengajak kebaikan serta mencegah kemungkaran, dan senantiasa beriman kepad Allah swt. (Depag RI, 2009). Dari penjelasan ayat diatas dapat dipahami bahwa seseorang dalam menjalani seluruh aktivitas hidupnya, akan dihadapkan pada sesuatu yang tidak sama, mereka ada pada level yang berbeda, yang dipahami dengan istilah struktur organisasi. Antara organisasi dengan pengaturan sumber daya lembaga tidak dapat dipisahkan satu sama lain. Sebab pengaturan sumber daya lembaga merupakan sumber yang berperan aktif jalannya suatu organisasi. The right man on the right place akan membawa suatu organisasi kepada hasil kinerja yang maksinal dan mengurangi kesalahan-kesalahan dalam tugas dan pekerjaannya.

Panti Asuhan sebagai sebuah organisasi melibatkan banyak individu yang memiliki kecenderungan yang berbeda satu sama lain, baik dari latar belakang pendidikan, sosial, bahkan sebagai individu yang memiliki karakteristik kepribadian yang juga berbeda antara satu dengan yang lain. Masing-masing individu saling bekerja sama untuk mencapai tujuan yang sama dari organisasi yang memfasilitasinya dan menaunginya. Panti Asuhan telah memberdayakan pengurusnya untuk melaksanakan job descriptionnya sesuai tupoksi yang telah ditetapkan, sangat berperan dan mendukung untuk membentuk atau membina akhlak anak asuh.

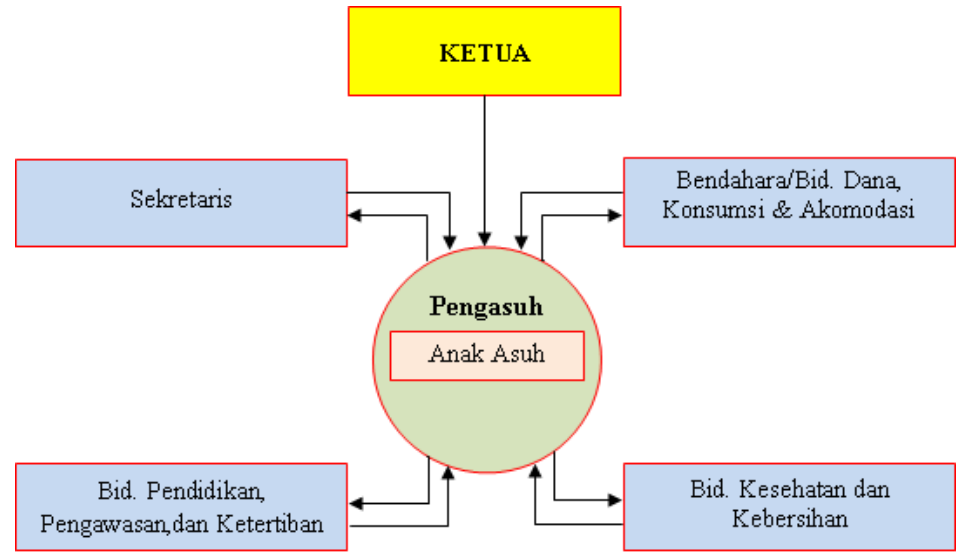

Gambar 1.

Organizing Sumber Daya Panti Asuhan Muhammadiyah Lhokseumawe Dalam Pembinaan Akhlak Anak Asuh 


\section{Kesimpulan}

Proses pengorganisasian yang dilakukan oleh Panti Asuhan Muhammadiyah Lhokseumawe dengan membentuk departementalisasi untuk memudahkan para pengurus dalam melaksanakan tugas yang telah diberikan sesuai bidangnya masing masing. Adanya penetapan garis pedoman kerja di Panti Asuhan sangat mendukung upaya peningkatan kelancaran dan ketertiban pengurus dalam menjalankan fungsinya yang pada gilirannya akan memudahkan tercapainya tujuan Panti Asuhan.

Organizing sumber daya Panti Asuhan Muhammadiyah Lhokseumawe dalam membentuk atau membina akhlak anak asuh, disesuaikan dengan tupoksi susunan kepengurusan atau struktur lembaga, antara lain Ketua, sekretaris, bendahara/bidang dana, konsumsi, dan akomodasi, bidang pendidikan, pengawasan dan ketertiban, bidang kesehatan dan kebersihan, dan bidang Pengasuhan.

Berdasarkan kepada job description pengurus, untuk penanganan masalah pembinaan akhlak anak asuh Panti Asuhan Muhammadiyah Lhokseumawe dipercayakan sepenuhnya pada bidang pengasuhan. Dalam menjalankan konsep atau kebijakan yang telah disepakati dalam musyawarah pengurus, bidang pengasuhan hanya mengikuti format yang telah digariskan. Ada bagian tertentu yang sifatnya teknis dan insidentil, bidang pengasuhan langsung mengambil kebijakan di lapangan selama kebijakan tersebut tidak bertentangan dengan format yang telah disepakati oleh pengurus.

\section{Daftar Pustaka}

Al-Abrasyi, Muhammad 'Athiyyah. (2003). Prinsip-Prinsip Dasar Pendidikan, terj. Abdullah Zaky al-Kaaf, Bandung: Pustaka Setia.

Al-Ghazali, Imam, Ihya' Ulumuddin, Juz 3, Beirut: Dar Ihya al-Kutub alIlmiyah, t.t.

Almuhajir, A. (2018). Manajemen Teungku Dayah: Pemberdayaan Personalia Lembaga Pendidikan Islam Di Aceh. Journal Analytica Islamica, 7(2), $117-$ 130.

Al-Sadiqi, Muhammad bin 'Ilan. (1391 H/1971). Dalil al-Falihin, Juz 3, Mesir: Mustafa al-Bab al-Halabi.

Al-Utsaimin, Muhammad bin Shalih. (2008). Makaarim al-Akhlak. Jakarta: Maktabah Abu Salma.

Arikunto, Suharsimi. (2006). Prosedur Penelitian: Suatu Pendekatan Praktik, Jakarta: Rineka Cipta.

Azmi, Muhammad. (2006). Pembinaan AkhlakAnak Usia Pra Sekolah, Upaya Mengefektifkan Nilai-nilai Pendidikan Islam dalam Keluarga, Yogyakarta: 
Belukar.

Burhanuddin. (1994). Analisis Administrasi Manajemen dan Kepemimpinan Pendidikan, Jakarta: Bumi Aksara.

Departemen Agama Republik Indonesia. (2009). Alquran dan Tafsirnya, Jakarta: Duta Grafika.

Departemen Pendidikan Nasional. (2005). Kamus Besar Bahasa Indonesia, Jakarta: Balai Pustaka.

Didin Hafidudin dan Hendri Tanjung. (2003). Manajemen Syariah dalam Prkatik, Jakarta: Gema Insani.

Dimyati, Mochammad. (2000). Penelitian Kualitatif: Paradigma Epistemologi, Pendekatan, Metode dan Terapan. Malang: PPS Universitas Negeri Malang.

Djatnika, Rahmat. (1994). Sistem Etika Islami (Akhlak Mulia), Jakarta: Balai Pustaka.

Fattah, Nanang. (2008). Landasan Manajemen Pendidikan, Bandung: Remaja Rosdakarya.

Fuadi et.al. (2013). "Pemenuhan Hak Anak Asuh Oleh Pengelola Panti Asuhan Menurut Hukum Islam dan Peraturan Perundangan-Undangan yang Berkaitan dengan Anak (Studi Penelitian di Kota Banda Aceh)," Jurnal Ilmu Hukum, 2(1).

Hasan, M. Ali. (1988). Tuntunan Akhlak, Jakarta: Bulan Bintang.

Hikmat. (2009). Manajemen Pendidikan, Bandung: Pustaka Setia.

http://news.unpad.ac.id. diakses tanggal 6 April 2019.

Jumhur dan Muhammad Suryo. (1987). Bimbingan dan Penyuluhan di Sekolah, Bandung: Ilmu.

Katsir, Ibnu. (2004). Tafsir Ibnu Katsir, Jilid 8, Bogor: Pustaka Imam Syafe’i.

Kharisma Nail Mazaya dan Ratna Supradewi. (2011). "Konsep Diri Dan Kebermaknaan Hidup Pada Remaja Di Panti Asuhan," Jurnal Psikologi Proyeksi, 6(2).

Leslie W. Rue \& Lioyd L. Byars. (2000). Manegement: Skills and Application, 8thed, Boston: The Irwin McGraw-Hill Companies.Inc.

Lia Hartati dan Winanti Siwi Respati. (2012). "Kompetensi Interpersonal pada Remaja yang Tinggal di Panti Asuhan Asrama dan yang Tinggal di Panti Asuhan Cottage," Jurnal Psikologi, 10(2). 
Mardotella, M., Fathurrochman, I., Sugiatno, S., Hamengkubuwono, H., \& Amin, M. (2019). Manajemen Dosen Penasehat Akademik dalam Meningkatkan Motivasi Kuliah Mahasiswa. ALIGNMENT: Journal of Administration and Educational Management, 2(2), 139-147.

Marzuki. (2009). Prinsip Dasar Akhlak Mulia (Pengantar Studi Konsep-Konsep Dasar Etika Dalam Islam), Yogyakarta: Debut Wahana Press.

Musthafa Kamal Pasha dan Ahmad Adaby Darban. (2000). Muhammadiyah sebagai Gerakan Islam (Dalam Perspektif Historis dan Ideologis), cet. I, Yogyakarta: LPPI.

Noer, Deliar. (1980). Gerakan Modern Islam di Indonesia 1900-1942, Jakarta: LP3ES.

Ristianti, D. H., Putrajaya, G., \& Fathurrochman, I. (2020). Organizational behavior management through group counseling discussions as a radicalism preventive effort. Jurnal Konseling dan Pendidikan, 8(1).

Saefullah. (2012). Manajemen Pendidikan Islam, Bandung: Pustaka Setia.

Syarief, A. Hamid. (1996). Pengembangan Kurikulum, Surabaya: Dina Ilmu.

Tim Penyusun. (1982). Pedoman Panti Asuhan, Jakarta: BPKPK

Tim Redaksi Pustaka Yustisia. (2010). Perundangan Tentang Anak, Yogyakarta: Pustaka Yustisia.

Tim Sosiologi. (2004). Sosiologi Suatu Kajian Tentang Kehidupan Masyarakat, Jakarta: Yudhistira.

Wibowo, Agus. (2013). Manajemen Pendidikan Karakter di Sekolah, Yogyakarta: Pustaka Pelajar.

Yanto, M., \& Fathurrochman, I. (2019). Manajemen kebijakan kepala madrasah dalam meningkatkan mutu pendidikan. Jurnal Konseling dan Pendidikan, 7(3), 123-130.

Zainuddin. (1999). Al-Isam 2 (Muamalah dan Akhlak), Bandung: Pustaka Setia. 